\title{
The Evaluation of Strengthening Character Education Program to Enhance Primary Students' Nationalism
}

\author{
A Senen ${ }^{1}$, M A Wulandari², I Muyassaroh ${ }^{3}$ \\ Departement of Primary Education Universitas Negeri Yogyakarta, Yogyakarta Indonesia ${ }^{1}$, \\ Departement of Primary Education Institut Keguruan \& Ilmu Pendidikan Siliwangi, Cimahi Indonesia ${ }^{2}$ \\ Departement of Primary Education Universitas Pelita Bangsa, Cikarang Indonesia ${ }^{2}$ \\ senen@uny.ac.id ${ }^{1}$, medita.aw@gmail.com², izzahmysr@gmail.com³
}

\begin{abstract}
This study aims to determine the effectiveness of strengthening character education program to enhance the value of nationalism in primary students of SD Negeri Cijeruk. This is an evaluative research using the CIPP Stuffebeam model which focuses in context, input, process and results. The data collected were using questionnaire, observation, interview, and documentation. The result shows that the strengthening character education program was $87,2 \%$ which is in "A" category. It shows that teachers and students have implemented the program in accordance with the objectives of national education curriculum. Recommendations for schools or the government is they need to provide "a nationalism checklist notebook" for students to motivate in implementing the nationalism values in their daily lives.
\end{abstract}

Keywords: Evaluation, Character Education, Nationalism, Primary Education.

\section{Introduction}

Education is a major factor that plays a role in shaping the human personality. National education has the function of developing capabilities and shaping dignified national character and civilization in order to educate the nation's life, aiming to develop the potential of students to become human beings who believe in God, have noble character, are healthy, knowledgeable, capable, creative, independent, and become a democratic and responsible citizen [1]. Character of the nation's is an important aspect of the quality of human resources because of the quality of a nation's character determines the progress of a nation. Quality characters need to be shaped and nurtured early and sustainably. The mandate of law number 20 of 2003 concerning the national education system is not only to form intelligent of Indonesians, but also to have a good character and personality, with the aim of forming a generation that grows and develops with characters that are in accordance with the noble values of their respective nations and religions.. Therefore, the real ultimate goals of education were to create an intelligent and character people.

Character is a form of morals attached to someone personality which formed from an internalization and used as a basic thinking and behaving, thus giving rise to a distinctive characteristic in these individuals [2]. Individual character will develop well, if it gets the right reinforcement, namely in the form of education. Character education is the creation of a school environment that helps students develop ethics, responsibility through the models and teaching good character through universal values [3]. These character values should be instilled in students so that they are able to apply in their lives both in the family, school, community, and country so that they can make a positive contribution to the environment. 
Primary school education level is the most appropriate time to instill character education [4]. The purpose of character education is to improve the quality of the implementation and outcomes that lead to the achievement of character building and noble character of students in a comprehensive, integrated and balanced manner [5]. Through character education, students are expected to be able to independently improve and use their knowledge, study and integrate and personalize the values of these noble characters and morals so that they are manifested in everyday life. Strengthening character education is a mandate of the ideals proclaimed by the president of the Republic of Indonesia which is contained in the eighth point concerning the procurement of a character revolution [6]. There are five main characters that become the priority for developing movements to strengthening character education, namely religious, integrity, independence, mutual cooperation, and nationalism.

Based on a survey conducted by Kompas Daily, the results show that there has been a degradation of character values in society, specially nationalism. The survey results show that only $65.9 \%$ of respondents said they were proud to be Indonesian. This number has drastically decreased compared to the previous year's survey data which reached $93.5 \%$. This shows, there are $5.1 \%$ of respondents who are not proud to be Indonesian citizens [7]. The survey shows that the currently the implementation of the cultivation of character values is an important thing to do, especially the value of the character of nationalism. The value of the character of nationalism is a way of thinking, behaving and acting that shows loyalty, concern and high respect for the interests of the nation and state are place above the interests of self and group. As for the main values of nationalism, the priority of strengthening character education in primary schools is obeying the law; discipline; love the motherland; respect for cultural, ethnic and religious diversity; appreciation of the nation's own culture; maintain the nation's cultural wealth; willing to sacrifice; excel and excel; as well as protecting the environment [8].

SD Negeri Cijeruk is one of the public primary schools in Dayeuhluhur-Cilacap, is a school that has a serious attention on strengthening character education in schools. It has been proven by the award that this school is selected as one of the best character school in the district. Therefore, this study conducted a deeper evaluation study in recognizing the strengthening of character education as an effort to instill the value of nationalism in the school.

\section{Method}

This is a qualitative research with evaluative type of research. This study aimed to determine the implementation of strengthening character education program to enhance students' nationalism. Evaluation is an activity of gathering information about the work of a thing, then the information is used to determine the right alternative in making a decision [9]. The evaluation methods used in this study were context, input, process and product or what is commonly known as CIPP [10]. This method focuses on evaluating the improvement of the results of the assessment that has been done. The research flow can be seen in the following figure: 


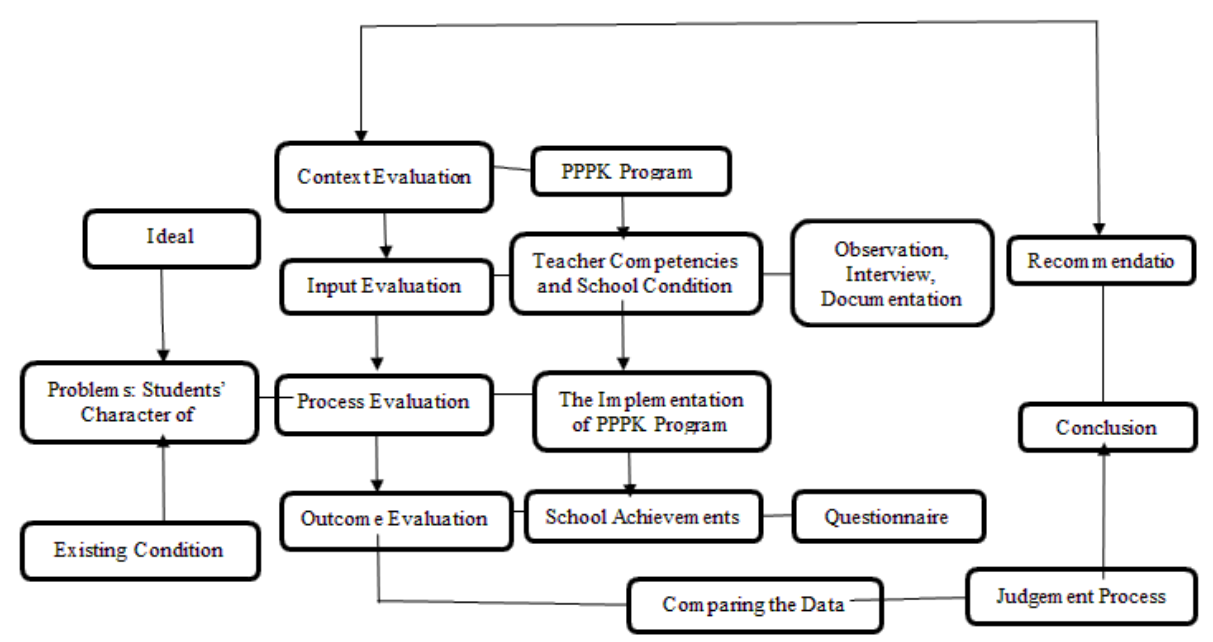

Fig.1. focuses on evaluating the improvement

This method focuses on evaluation on the improvement of the results of the assessment that has been done. The main reason for using CIPP evaluation models is the comprehensiveness and further application, Because of some of information can be Obtain ed in terms of desirable object, operational programs and executive result to help improve academic activities. The subjects of this study were 161 people consist of all students in grades 1 through 6 at SD Negeri Cijeruk, totaling 152 students, 6 class teachers, 1 religion teacher, 1 sport teacher, and 1 school principal. The data collection technique was using questionnaire, observation, interview and documentation methods. The data collected data were analyzed through data reduction, data display and data verification [11].

\section{Result And Discussion}

\subsection{Context Analysis}

The strengthening character education program is an educational movement in schools to strengthen student character through harmonization of heart (ethics), feeling (aesthetics), thought (literacy), and sports (kinesthetic) with the support of public involvement and cooperation between schools, families, and society. The movement to strengthen character education is part of the national mental reform movement which has five main values of priority characters, namely religion, nationalism, help each other, integrity, and independence. The strengthening character education program has the following benefits [12]: 1) strengthening student character in preparing students' competitiveness with 21 st century competencies, namely critical thinking, creative thinking, being able to communicate and collaborate; 2) integrated learning is carried out at school and outside the school with teacher supervision; 3) revitalizing the role of school principals as managers and teachers as inspirations for the movement to strengthen character education; 4) revitalization of the school committee as a school mutual cooperation and community participation body; 5) strengthening the role of the family through the five-day learning policy; and 6) collaboration between the 
central government, local governments, community organizations, education activists, cultural activists and other learning sources.

The focus of strengthen character education is [13]: 1) a program structure that is focused on the primary and junior high school levels by utilizing the existing education ecosystem in the school environment and strengthening the capacity of school principals and teachers. Parents, school committee and other relevant stakeholders; 2) curriculum structure that does not change the existing curriculum but rather optimizes the curriculum in educational units through intra-curricular, co-curricular and extra-curricular activities, as well as non-curricular activities in the school environment; and 3) the structure of activities that invites each school to find its characteristics so that the school becomes very rich and unique as well as realizing the four-dimensional character building activities initiated by Ki Hajar Dewantara, including taste, heart, mind, and sports.

The bases of strengthening character education program are: 1) class-based where the integration of the learning process in the classroom through the curriculum in subjects, both thematically and integrated; strengthening classroom management and choice of teaching methodology and evaluation; as well as developing local content according to regional needs. 2) based on school culture where the values in the daily school are habituated; exemplary adults in an educational environment; involving the school ecosystem; wide space for all potential students through co-curricular and extra-curricular activities; empowering school management; and taking into account the school's regulatory norms and traditions. 3) community based, where the environmental potential as a source of learning, such as the existence and support of the business world and the industrial world; synergy of strengthening character education programs with various existing programs in academia, educational activists and non-governmental organizations; synchronization of programs and activities in collaboration with local governments as well as communities and parents of students

\subsection{Input Analysis}

SD Negeri Cijeruk was founded in 1980, this school is located on road Cijeruk-Sawah Tengah, Cijeruk village, Dayeuhluhur subdistrict, Cilacap district. SD Negeri Cijeruk has a good physical school condition with 6 classrooms, 1 mosque, 1 library, 2 student sanitation and 1 teacher sanitation. The results of observations on school physical facilities are already good, starting from the principal's room, teachers' room, places of worship, libraries, classrooms, sanitation, ceremonial fields, props that support the formation of student character including the delivery of media and teaching materials that can foster the value of nationalism. Apart from the good physical condition of the school, this school is supported by competent teachers. A documentary study of the data on principals, teachers and employees shows that all teachers and principals who have at least a bachelor's education qualification and have an educator certificate. The number of teachers in the school is 8 people consisting of 6 class 1 religion teachers and 1 sports teacher. As well as one principal. The results of the documentation study showed that the total number of students at the school was 153 students, of which 62 were male students and 89 were female students.

The interviews data with the principal and teachers provided information that the factors that support the implementation of the strengthening character education program in the school are because SD Negeri Cijeruk has been selected to be one of the character schools in Cilacap district since 2018. Other supporting factors include the existence of a school principal and outstanding teachers at the school. This was conveyed by the school principal 
that he was chosen to be one of the outstanding school principals in the Dayeuhluhur subdistrict and one of the class teachers was also selected as an outstanding teacher at the subdistrict level. The existence of principals and teachers with character in a learning environment will be able to help students cultivate character values in themselves [12].

\subsection{Process Analysis}

Based on interviews with school principals and teachers, data was obtained that the school was really trying to meet the facilities needed in implementing the character education strengthening program at the school. In addition, the observation and documentation data also show some unique findings of the implementation of the character education strengthening program in SD Negeri Cijeruk, including the following activities.

\section{a. Ceremony}

The ceremony is held every week, namely on Monday morning. The Monday morning ceremony is a routine weekly ceremony for SD Negeri Cijeruk. Apart from the routine Monday morning ceremony, SD Negeri Cijeruk also routinely hold national holiday ceremonies. If in the same week there is a national holiday celebration, usually Monday morning events are abolished and replaced with a national holiday ceremony. This is in line with Bahtiar's statement which states that one way to develop an attitude of nationalism for elementary school students is to routinely carry out flag ceremonies [3].

\section{b. Scout Extracurricular Activities}

SD Negeri Cijeruk requires all grade 4 and 5 students to take part in extra-curricular scout activities at the school. This activity is carried out in addition to preparing students to take part in scouting activities which are held every year and also aims to instill nationalistic values in students in a fun way. This is in line with Surono's opinion which states that scout extracurricular activities can instill the values of nationalism in students [14].

\section{c. Use of Traditional Clothes \& Local Languages}

SD Negeri Cijeruk requires all school members, namely the principal, teachers and students to wear national traditional clothes and use the regional language on Wednesdays every week. The traditional clothes used are typical Sundanese clothes, namely pangsi and iket for men and kebaya for women. Then the regional language they use is Sundanese according to its geographical position. This is in line with Keraf 7 Komalasari's statement which states that the use of traditional clothes and regional languages is one of the habituations that schools can do as an effort to strengthen the nationalistic character of students [15].

\section{d. Golden Class Program}

The Golden Class program is the flagship program of SD Negeri Cijeruk in implementing the nationalistic values of their students. The development of nationalism values with this program, for example, every day before starting learning, all students and teachers are accustomed to singing the national compulsory song and regional songs, the names of the picket group and the study group in each class are named with the names of national or regional heroes. There is an eagle symbol as well as a photo of the president and vice president in each class. then this school also routinely raises the red and white flag every day. These activities are a series of activities which aim to instill the values of nationalism in students.[16] 


\subsection{Product Analysis}

This analysis was obtained through a student questionnaire that had been calculated and adjusted to the criteria for achieving the strengthening character education program. The questionnaire data of all students shows that they are "sometimes, often and always" do the nationalism rules. There were no students' answers "never". Problem number 1 gets a score of 5 and is in the "always" category, which is equal to $100 \%$. Students who answer on a score of 4 or category are often in question number 7 , namely $80 \%$. Students who answered on a score of 4 or the category "often" were in question number 7, namely $34-35 \%$.

The results of the student questionnaire analysis showed that the total score was 10931 with a maximum value of 12535 . Then to find the results of the evaluation value on the achievement of the character education strengthening program in SD Negri Cijeruk, it can be seen in the following calculations:

$$
10931 / 12535 \times 100 \%=87.2 \%
$$

The percentage of the results of the achievement of the character education strengthening program in SD Negri Cijeruk of $87.2 \%$ is adjusted to the category of assessment that has been made, which is in category A which means the character education strengthening program has been carried out very well and according to expectations.[17]

\section{Conclusion}

Implementation of strengthening character education program to enhance nationalism in SD Negeri Cijeruk has been successfully implemented by the school. the ability of principals and teachers in designing and implementing strengthening of character nationalism in students is excellent, so that students begin to get used to integrating the values of nationalism in their daily activities, especially at school. The achievement level of strengthening character education program in the school is $87,2 \%$ which is in grade $\mathrm{A}$, it shows that students have implemented the strengthening of nationalism character properly in accordance with the designs and expectations of teachers.

\section{References}

[1] Undang-Undang no. 20 Tahun 2003 tentang Sistem Pendidikan Nasional Pasal 3.

[2] Tim Penyususn kamus Bahasa Indonesia. 2008. Kamus Bahasa Indonesia. Jakarta: Pusat Bahasa Departemen Pendidikan Nasional.

[3] Berkowi, Z. M. W., \& Bier, M. C. 2005. What Works In Character Education: A Research-Driven Guide for Educators. Washington DC: University of Missouri St Louis.

[4] Khotimah, D. N. 2019. Implementasi Program Penguatan Pendidikan Karakter (PPK) Melalui Kegiatan 5S di Sekolah Dasar. Inopendas Jurnal Ilmiah Kependidikan, Vol. 2 No. 1, hal. 28-31. 
[5] Kementrian pendidikan Nasional. 2010. Pengembangan Pendidikan Budaya dan Karakter bangsa: Pedoman Sekolah. Jakarta: Badan Penelitian dan Pengembangan Pusat Kurikulum.

[6] Pusbindiklatren. 2018. Menuju Perencanaan Profesional: SIMPUL Perencanaan. Jakarta: BAPPENAS.

[7] Tukiran, T. 2011. Pendidikan Multikultural dan Nasionalisme Indonesia. Jurnal SOSIO DIDAKTIKA: Sosial Science Education Journal, Vol 1 No. 1, hal. 29-36.

[8] "Program Penguatan Karakter" Kemdikbud.go.id/main/blog/2017/07/penguatan-pendidikan-karakter-jadi-pintumasuk-pembenahan-pendidikan-nasional.

[9] Arikunto, S, \& Jabar, C. S. A. 2014. Evaluasi Program Pendidikan Pedoman Teoritis Praktis Bagi Mahasiswa dan Praktisi Pendidikan. Jakarta: Bumi Aksara.

[10] Bernardo, F., \& Palma, J. M. 2005. Place and Identity Process. Medio Ambiente Compotamiento Humano, Vol 6 No. 1, hal 71-87.

[11] Miles, M. B., \& Heberman, A. M. 2014. Analisis Data Kualitatif: Buku Sumber Tentang Metode Penelitian. Terjemahan Tjetjep Rohendi Rohidi. Jakarta: UI-Press.

[12] Kemantrian Pendidikan dan Kebudayaan. 2017. Konsep Dasar Penguatan Pendidikan Karakter „Senang belajar di Rumah kedua“. http://alihfungsi.gtk.kemdikbud.go.id/assets/konsep_karakter.pdf (diakses tanggal 13 Juni 2020)

[13] Kemantrian Pendidikan dan Kebudayaan. 2017. gerakan Penguatan Pendiidkan karakter. http://repositori.kemdikbud.go.id/10096/1/Paparan_PPK_Dr_Arie_Budhiman_M_Si.pdf (diakses tanggal 13 Juni 2020)

[14] $\bar{A}$ jman \& Marzuka. 2019. peran Guru dan kepala Sekolah dalam Pendidikan Karakter Siswa di SMA Negeri 3 Yogyakarta. Jurnal Ilmu Sosial, Vol 16 No. 1, hal 109-123.

[15] Bahtiar, R. S. 2016. Upacara Bendera Berbasis Karakter dalam Pengembangan Sikap Nasionalisme Siswa. INOVASI, Vol. 7 No. 2, hal 71-76.

[16] Surono, K. A. 2017. Penanaman Karakter dan Rasa Nasionalisme pada Kegiatan Ekstrakurikuler Pramuka di SMP N 4 Singorojo Kabupaten Kendal. Indonesia Journal of Conservation, Vol. 6 No. 1, hal 23-30.

[17] Keraf, F. M. P., \& Komalasari, K. 2019. Penguatan Pendidikan Karakter Nasional Melalui Habituasi pada Siswa SMP Wilayah Perrbatasan Indonesia-Timor leste. Jurnal Penelitian Pendidikan, Vol. 1 No.1, hal 201-211. 